\title{
Late Quaternary Geomorphology of the Tonami Plain and Activity of the Tonami-Heiya Fault Zone, Toyama Prefecture, Central Japan
}

\author{
Toshio Kamishima*, Akira Takeuchi \\ Graduate School of Science and Engineering, University of Toyama, Toyama, Japan \\ Email: *toshi-kami@cpost.plala.or.jp
}

Received 18 March 2016; accepted 23 July 2016; published 26 July 2016

Copyright (C) 2016 by authors and Scientific Research Publishing Inc.

This work is licensed under the Creative Commons Attribution International License (CC BY). http://creativecommons.org/licenses/by/4.0/

(c) (i) Open Access

\section{Abstract}

The Holocene alluvial fans and flood plains formed by the Sho and Oyabe Rivers spread out in the Tonami plain from the central through the northern parts in the Toyama Prefecture, central Japan. Along the foot of the surrounding mountains and hills, higher, middle and lower terraces of late Pleistocene-Holocene in age are distributed. These terraces have been displaced, by the reverse dip-slip activities of Tonami-heiya fault zone in a sense of upheaval in the mountains side, even during the Holocene time. We examined stratigraphic cross section utilizing borehole data and geomorphologically analyzed $5 \mathrm{~m}$-DEM data in order to elucidate the fault trace of the Isurugi fault which Tonami-heiya fault zone. As the results, the northern segment of Isurugi fault seems to run along the northeastern foot of Hodatsu Hills and extends underground through the lower-most Oyabe River into the Toyama Bay. Consequently, its total length reaches about $30 \mathrm{~km}$. In the southern segment, a continuous fault scarplet was recognized to cut across the lower dissected fans. The slip-rate of Isurugi fault is estimated to be $0.31-0.64 \mathrm{~m} / \mathrm{kyr}$. In the Hokuriku region, reverse faulting and related folding with strike in a NE-SW direction have occurred during the late Quaternary. The hinge line of block movement due to the activities of the Tonami-heiya fault zone is revealed to have shifted from the mountain side into the plain side within the Holocene time. In conclusion, the Quaternary folding and faulting associated with the crustal warping at a wavelength of about $20 \mathrm{~km}$ is currently in progress, causing both the subsidence of Tonami plain and the upheaval of surrounding mountains and hills.

\section{Keywords}

Tectonic Geomorphology, Late Quaternary, Active Fault, Tonami Plain, Central Japan

\footnotetext{
${ }^{*}$ Corresponding author.
}

How to cite this paper: Kamishima, T. and Takeuchi, A. (2016) Late Quaternary Geomorphology of the Tonami Plain and Activity of the Tonami-Heiya Fault Zone, Toyama Prefecture, Central Japan. International Journal of Geosciences, 7, $962-976$. http://dx.doi.org/10.4236/ijg.2016.77073 


\section{Introduction}

The Toyama Plain is located on the Japan Sea side of central Japan. It lies between the 1000 m-deep Toyama Bay in the north and the 3000 m-high Hida Mountain range and the 1500 m-high Hida Highland in the south. The Toyama Plain was formed primarily by new and old fans created by a group of rivers flowing steeply down from the mountains behind it.

The western part of the Toyama Plain, called as the Tonami Plain is narrow, at roughly 35 km long and 10 to $15 \mathrm{~km}$ wide, running landward in a SW direction from Toyama Bay (Figure 1). Spread over the middle of the plain are many alluvial fans created by the two major rivers, the Sho and the Oyabe Rivers. Spread over the northern part of the plain, in the lower reaches of the two rivers, are such natural features as floodplains, natural levees, and back marshes. Distributed at the foot of the surrounding mountains are higher, middle, and lower fluvial terraces, dissected fans, and marine terraces.

The area surrounding the Tonami Plain consists of, in the north, the Futagami Hills; in the northwest to west, the Hodatsu Hills and Tonamiyama Hills; in the southwest, the Iozen Mountains extending north from the Ryohaku Mountains; in the southeast, the Takashozu Mountains; and in the east the Shoto Mountains extending north from the Hida Highland as the altitude gradually declines and Imizu Hills. These hills and mountains surround the Tonami Plain in all directions except in the northeast, where the plain opens on to Toyama Bay and the Imizu Plain. Thus the Tonami Plain takes the form of a semi-basin (Figure 1 and Figure 2).

In addition, the outline of the boundary between these mountains and hills and the Tonami Plain is straight and simple. Many active faults exist in this area, which is generally referred to as the Tonami-heiya fault zone [1]. The Tonami-heiya fault zone is divided into western and eastern parts. Included in the western part of the fault zone is the Isurugi fault, located at the southeastern foot of the Hodatsu Hills, and the Horinji fault, located at the southeastern foot of the Iozen Mountains. Included in the eastern part of the fault zone is the Takashozu fault (Figure 1 and Figure 2).

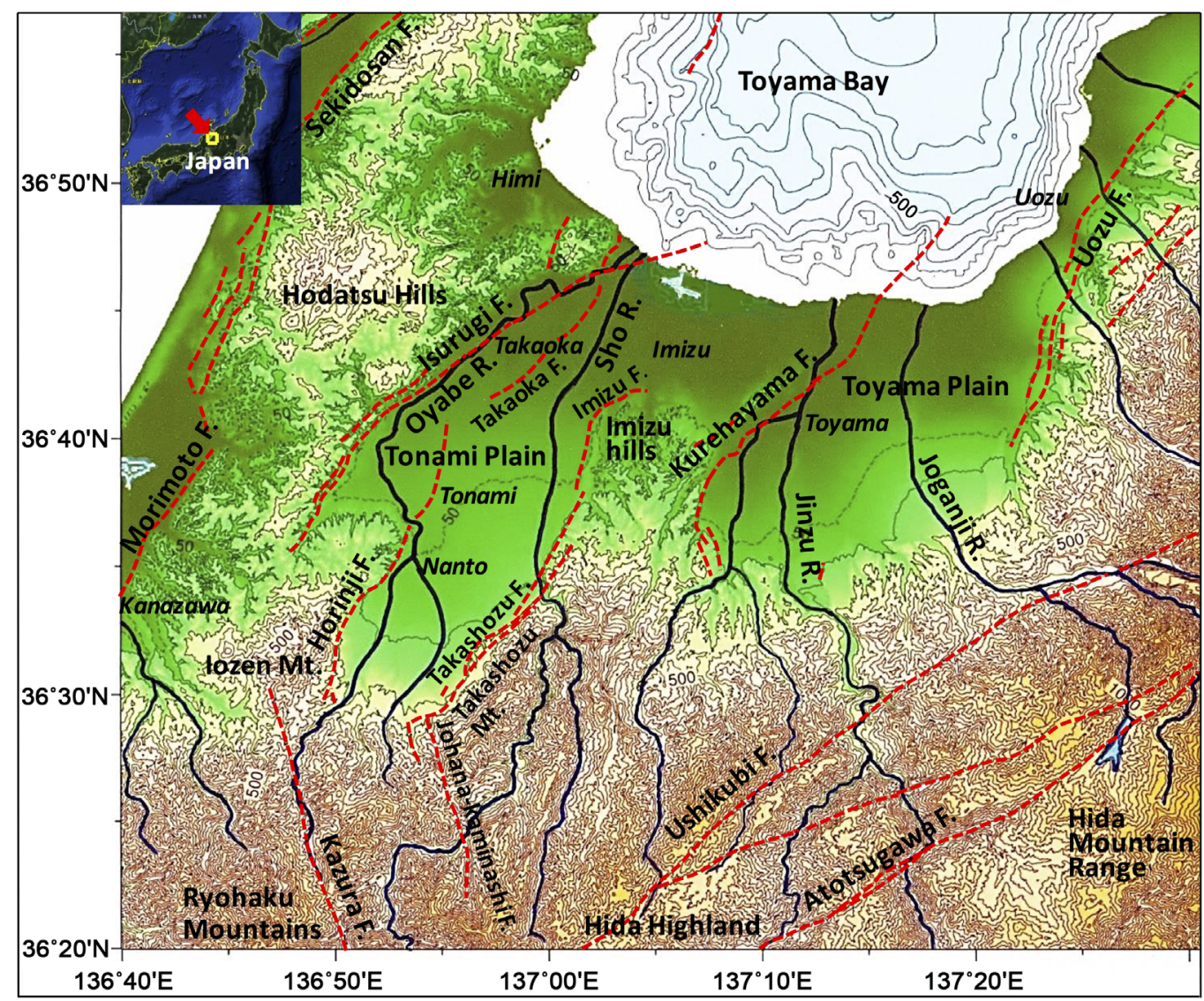

Figure 1. Topography and active faults in and around Tonami Plain (Based on the map of GSI). 


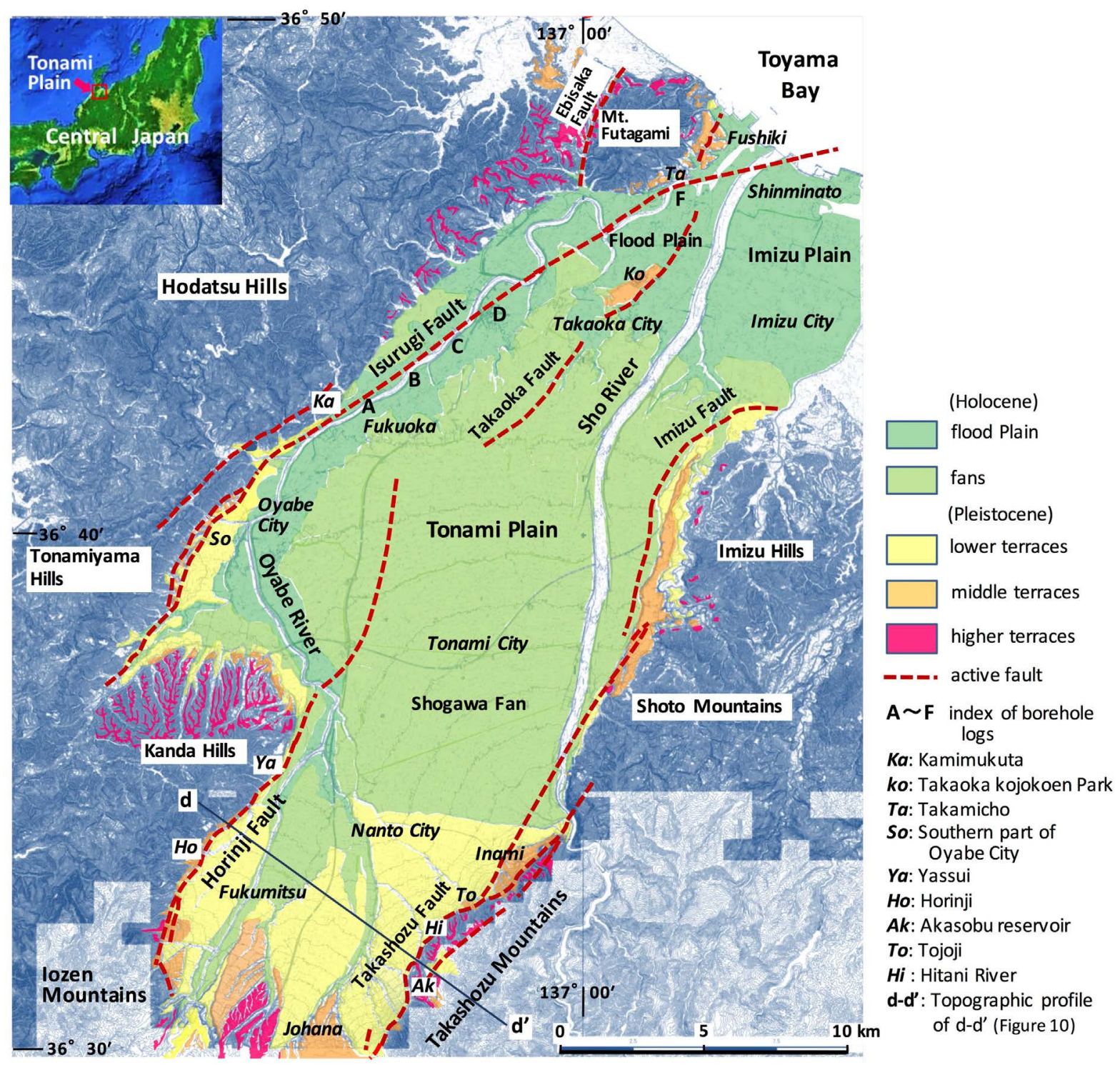

Figure 2. Landform classification map of late Quaternary in the Tonami Plain. The radical map is $1 \mathrm{~m}$ contour line plot made from $5 \mathrm{~m}$-DEM of GSI. The mountainous area in the southern part adopts 10m contour line of 1:25,000 Topographical map.

\section{Purpose and Method of Research}

The evolution of the landforms and geology of the Tonami Plain is thought to have begun in the Quaternary after the end of the previous Neogene tectonic movements [2] [3]. For this reason, the objective of this study was to elucidate the formation of the landforms of the Tonami Plain mainly in the late Quaternary and the role played by active faults in this formation process.

To achieve this objective, the following methods were employed. In the case of the Isurugi fault located in the western part of the Tonami-heiya fault zone, the location of the master fault, which is thought to be concealed under the northern part of the Tonami Plain, was estimated by correlating the stratigraphy of borehole logs for snow-melting wells. In the southern part of the plain, a landform classification map and topographic profile were created on the basis of [4] 5 m-DEM and used to estimate the location of the fault.

The characteristics of the Horinji fault in the western Tonami-heiya fault zone and the Takashozu fault in the eastern fault zone were studied by using fault outcrop observation and trench survey results. In addition, a topo- 
graphic profile was created on the basis of the $5 \mathrm{~m}$ DEM of [5] and used to determine the characteristics of both faults.

The results were compiled by using the abovementioned research methods and then used to discuss the relationship between the geomorphic evolution of the Tonami Plain and the movement of active faults in the late Quaternary.

\section{Overview of the Landforms and Geology of the Tonami Plain and Its Surrounding Areas, and the Locations of Active Faults}

\subsection{Overview of the Geology of the Area Surrounding the Tonami Plain before the Middle Quaternary}

The geological foundations of the Hokuriku region, including the Hida metamorphic rocks and granite of the Mesozoic era or of an earlier era and the Nohi rhyolites and Futomiyama group of the Paleogene, are widely distributed in the northern part of the Hida Highland.

Later on, in the early Miocene of the Cenozoic era, the Iwaine formation and the Iozen formation, for example, were created by submarine volcanic eruptions that occurred along with the expansion of the Sea of Japan. In the middle Miocene, the Toyama sedimentary basin was formed by subsidence; marine sediments accumulated in this area, and the Kurosedani formation and the Higashibessho formation were created. Similarly, in the late Miocene, the Otogawa formation and others were created.

From the Pliocene to the early Pleistocene of the Quaternary, the Takakubo, Yabuta, and Junicho formations sedimented in the area surrounding the Tonami Plain, and from the early to the middle Pleistocene the Onma and Hanyu formations sedimented in the same area [6] [7].

Because the start of the Quaternary is now placed at roughly 2.588 Ma years ago (e.g., [8]), in this study, the Onma and Hanyu formations that had traditionally been considered to belong to the early Pleistocene are included in the middle Pleistocene and the higher terraces that were once said to belong to the middle Pleistocene are included in the late Pleistocene.

[9] referred to the transformation of the tectonic movements of the Neogene into the tectonic movements of the Quaternary as the Isurugi deformation; they considered this to be the period when the Onma and Hanyu formations were unconformably covered by higher terrace gravel. [3] divided the geomorphic evolution of the Sea of Japan and Hokuriku region during the Cenozoic era into five stages. According to this division, the fifth stage is the present tectonic period that began 4 Ma years ago and continues to the present; the present NE-SW active structure started forming during this stage, and this was deeply related to the formation of such landforms as the present Hida Mountain range, Noto Peninsula, Toyama Bay, and Toyama Plain. [3] also pointed out that sediments are still accumulating in the Neogene sedimentary basins of the Hokuriku region and forming alluvial plains.

\subsection{Landforms and Geology of the Tonami Plain in the Late Quaternary}

\subsubsection{Higher Terrace Gravel}

On the Tonami Plain, terrace sediments accumulated in the late Pleistocene and are presently distributed mainly at the foot of the surrounding mountains and hills. The rivers that supplied these sediments were the Sho, the Oyabe, and their tributaries (Figure 2).

The higher terrace sediments unconformably cover the Hanyu formation of the middle Pleistocene. Although not much of them are left on the terrace surface, they are generally tilted toward the plain. Generally, the higher terrace gravel is seriously weathered, and most of it has now become decayed gravel bed. The thickness of the red to reddish brown soil on top of the gravel is mostly between 2 and $3 \mathrm{~m}$.

On the southern part of the Tonami Plain, at the northeastern foot of the Takashozu Mountains, new activity of the Takashozu fault can be observed at the front of the higher terraces. In the upper river basin of the Oyabe River, the terrace surface is fairly well preserved. In the Kanda Hills at the northern foot of the Iozen Mountains, the valleys that erode the hills have formed unevenly. The valleys that run from south to north or northwest are well developed, but those that run to the east are small in scale. On the northern part of the Tonami Plain, the higher terraces are widely distributed in the area from the southeastern foot of the Hodatsu Hills to the ridges 
near the Ebisaka Pass [10].

\subsubsection{Middle Terrace Surface and Terrace Gravel}

Many middle terrace surfaces on the Tonami Plain are in the form of dissected fans; such terraces with two or three levels, each formed at a different time, are distributed on the right bank of the Sho River on the eastern part of the Tonami Plain and in the basin of the Oyabe River on the southern part of the Tonami Plain. On the northern part of the Tonami Plain, marine terraces are distributed in the Fushiki area near the Futagami Mountains (Figure 2).

Although the surfaces of these middle terraces is heavily dissected, wide undissected areas can still be observed. Field survey results indicate that although the terrace gravel is beginning to weather, the percentage of decayed gravel is low. On top of the gravel is a 1.5- to 2.0-m-thick brown to reddish brown soil. In some cases, a distal tephra layer can be found in between layers of this soil. For example, the Daisen Kurayoshi pumice (DKP tephra) is said to have fallen roughly 55,000 years ago [11], and the location of this pumice in the soil can be used to estimate the time of sedimentation of the middle terrace gravel.

\subsubsection{Lower Terrace Surface, Terrace Gravel, and Holocene Depositional Surface}

On the southern part of the Tonami Plain, [12]-[14], and others classified the higher to lower terrace surfaces.

Many lower terrace surfaces on the Tonami Plain are also dissected fans. On the southern part of the Tonami Plain they are widely distributed from the area along the Sho River to the area along the Oyabe River and surround the higher terrace and middle terrace surfaces. They are also distributed near the southern part of the city of Oyabe and on the right bank of the Sho River (Figure 2).

Downstream along the Sho and the Oyabe Rivers, if these lower terrace surfaces have not been eroded by the rivers they are often covered by alluvial sediments. These lower terrace surfaces can be further classified into about three levels, although this number differs from location to location. In the southern part, the Aira-Tn tephra (AT) layer can be found between the upper layers of the lower dissected gravel fan. This tephra fell about 26,000 to 29,000 years ago [11]; therefore, it can be estimated that the terrace gravel was formed at about this time [15].

A large alluvial fan formed by the Sho River spreads out and covers about half of the central part of the Tonami Plain. The Oyabe River also forms a small fan. Both fans are composed mainly of gravel. At the ends of the fans, sand and silt layers are mixed in between the gravel layers. Along the lower reaches of both rivers a floodplain spreads out and there are natural levees and back marshes. In this area, alternating strata of gravel, sand, and silt are frequently observed. Holocene sediments cover a large area of the Tonami Plain.

On the Tonami Plain, the depositional surface that is estimated to have been created in the Holocene forms a lower terrace. This is seen mostly in the area near the apex of the Sho River fan and in the lower river regions of the Oyabe and Sho rivers on the northern part of the Tonami Plain. The reason behind this is assumed to be the uplifting of the mountain side of the fault and the effect of the erosion that has continued since the Jomon transgression.

\subsubsection{Sediments Beneath the Tonami Plain}

[16] estimated the thickness of the alluvium on the Tonami Plain to be as follows. On the northern part of the Plain, the thickness was estimated to be between 20 and $30 \mathrm{~m}$ near the city of Takaoka and about $25 \mathrm{~m}$ in the northern part of Toide. In the Sho River fan located in the central part of the Tonami Plain, the thickness was estimated to be roughly $30 \mathrm{~m}$. [17] conducted a boring survey in the northern part of Toide in the city of Takaoka (altitude roughly $23 \mathrm{~m}$ ) and estimated the Hanyu formation to lie at a depth of 40 to $440 \mathrm{~m}$. On the other hand, [18] estimated the maximum depth to the base of the Quaternary strata (the Junicho stratum in this case) on the northern part of the Tonami Plain to be $-2000 \mathrm{~m}$.

\subsection{Characteristics of Active Faults in the Tonami-Heiya Fault Zone}

The characteristics of active faults that comprise the Tonami-heiya fault zone, including the Isurugi and Horinji faults on the western part of the Tonami Plain, the Takashozu fault on the eastern part, and other active faults associated with these faults, are summarized in Table 1. 
Table 1. Feature of Tonami-heiya fault zone.

\begin{tabular}{|c|c|c|c|c|}
\hline \multirow{2}{*}{$\begin{array}{c}\text { Classification } \\
\text { Fault name }\end{array}$} & \multicolumn{2}{|c|}{ Tonami-heiya fault zone (western part) } & \multicolumn{2}{|c|}{ Tonami-heiya fault zone (eastern part) } \\
\hline & $\begin{array}{l}\text { Horinji fault, Takaoka fault, } \\
\text { Isurugi fault }\end{array}$ & Ebisaka fault & $\begin{array}{l}\text { Takashozu fault } \\
\text { Imizu fault }\end{array}$ & $\begin{array}{c}\text { Johana-Kaminashi fault } \\
\text { Futatsuyagawa fault }\end{array}$ \\
\hline Length & $26 \mathrm{~km}-40 \mathrm{~km}$ & $5 \mathrm{~km}$ & $>21 \mathrm{~km}$ & $15 \mathrm{~km}$ \\
\hline Width & $20-30 \mathrm{~km}$ & unknown & unknown & unknown \\
\hline Strike & $\mathrm{N} 40^{\circ} \mathrm{E}$ & $25^{\circ} \mathrm{N}-30^{\circ} \mathrm{E}$ & $\mathrm{N} 30^{\circ} \mathrm{E}$ & $\mathrm{N} 10^{\circ} \mathrm{W}$ \\
\hline Dip & $45-50^{\circ} \mathrm{NW}$ & $\mathrm{E}$ & $20^{\circ}-80^{\circ} \mathrm{SE}$ & $\mathrm{E}$ \\
\hline Type & reverse, NW up & reverse, E up & reverse, SE up & reverse, E up \\
\hline Slip rate (vertical) & $0.3-0.6 \mathrm{~m} / \mathrm{kyr}$ & unknown & $0.3-0.4 \mathrm{~m} / \mathrm{kyr}$ & unknown \\
\hline Activity time & $\begin{array}{l}\text { Horinji: } 5600 \text { years ago or later } \\
\text { Isurugi: } 4000 \text { - } 900 \text { years ago }\end{array}$ & $\begin{array}{l}\text { Higher terrace } \\
\text { gravel later }\end{array}$ & 4300 - 3600 years ago & 100,000 years ago and later \\
\hline Activity interval & $\begin{array}{l}\text { Horinji: } 4900 \text { within years } \\
\text { Isurugi: about } 2000 \text { years }\end{array}$ & unknown & 3000 - 7000 years & unknown \\
\hline
\end{tabular}

(Edited from [1], [24], [30], [36]).

\subsubsection{The Isurugi Fault}

The Isurugi fault is thought to run along the eastern foot of the Tonamiyama Hills in the southern part of the city of Oyabe and along the southeastern foot of the Hodatsu Hills; it then passes along the Oyabe River and reaches Toyama Bay ([19], Figure 1 and Figure 2).

In previous studies, [20]-[23], and many others have described the Isurugi fault as active. [24] and [25] observed outcropping of a back thrust with upheaval of the plain side on the lower terrace in the Kamimukuta area of Fukuokamachi (Ka of Figure 2), in the city of Takaoka; they estimated that the Isurugi fault was active from roughly 4000 to 900 years ago, with an average activity interval of about 2000 years. [26] and [27] conducted a shallow seismic reflection survey in a SE-NW direction across the Tonami Plain and found that, in the northern part of the city of Oyabe, the Isurugi fault was a reverse fault with an uplifted western side. They estimated the location of the master fault to be near the Oyabe River.

To trace the Isurugi fault, [19] correlated the stratigraphy of borehole logs for snow-melting wells and estimated the location of the master fault. The results suggested that the master fault for the Isurugi fault was concealed along the Oyabe River; the estimated length of the fault was about $30 \mathrm{~km}$ (Figures 2-5).

A comparison of the borehole logs distributed in area A and B with the estimated the location of the Isurugi fault. Note that the arrangements of the borehole logs were changed on the basis of the location of the Isurugi fault. Holocene (green) described the found part only.

In addition, in the southern part of Oyabe (So of Figure 2), [4] topographic map data (5 m-DEM) aerial photograph decipherment were combined to obtain the location of the extension of the Isurugi fault. About four faults were estimated to exist in the area between the eastern foot of the Tonamiyama Hills and the lower dissected fans in the east (Figure 6).

Moreover, in the northern part, a fault displacement rate of 0.31 to $0.64 \mathrm{~m} / \mathrm{kyr}$ was obtained on the basis of the correlation of the elevation of middle terrace surfaces containing the distal tephra, namely the Daisen Kurayoshi tephra (DKP) ( $\mathrm{Ta}$ and Ko of Figure 2). When this value was used to estimate the accumulated displacement in the Quaternary, which is about 2.6 Ma years, it amounted to 806 to $1664 \mathrm{~m}$.

\subsubsection{The Horinji Fault}

The Horinji fault lies at the southeastern foot of the Iozen Mountains, on the southwestern part of the Tonami Plain (Figure 1 and Figure 2). The higher, middle, and lower terrace gravels, and others that are steeply tilted or cut by the fault, can be observed along it. According to [28]-[30], pit surveys in the Yassui area(Ya of Figure 2) of the city of Nanto have confirmed the existence of a reverse fault, the northwestern mountain side of which is uplifted, cutting the lower terrace sediments. Topographic displacement caused by the fault has also been confirmed in the nearby area. 


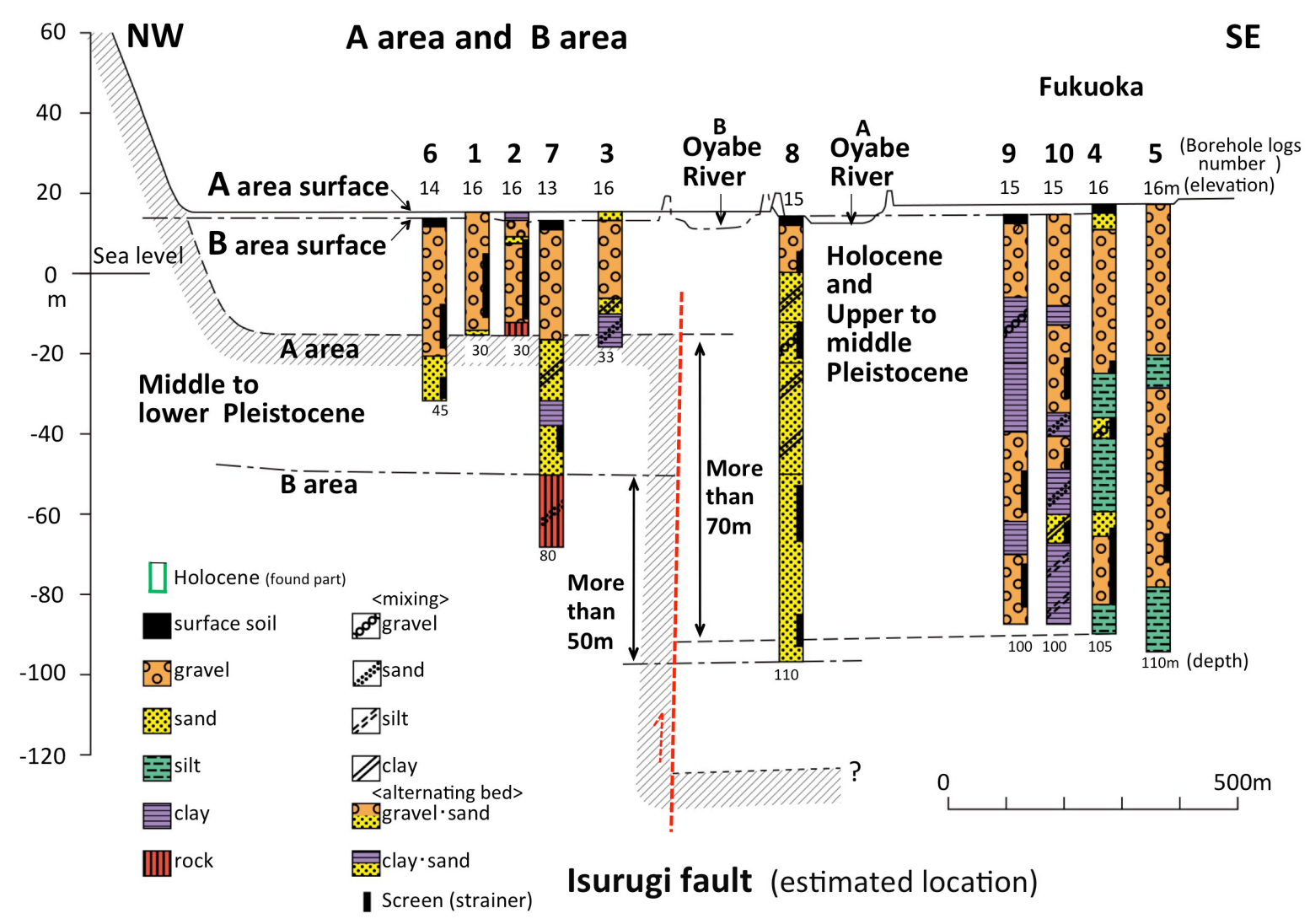

Figure 3. Correlation of borehole logs (number 1 - 10) in A area and B area and estimated location of the Isurugi fault.

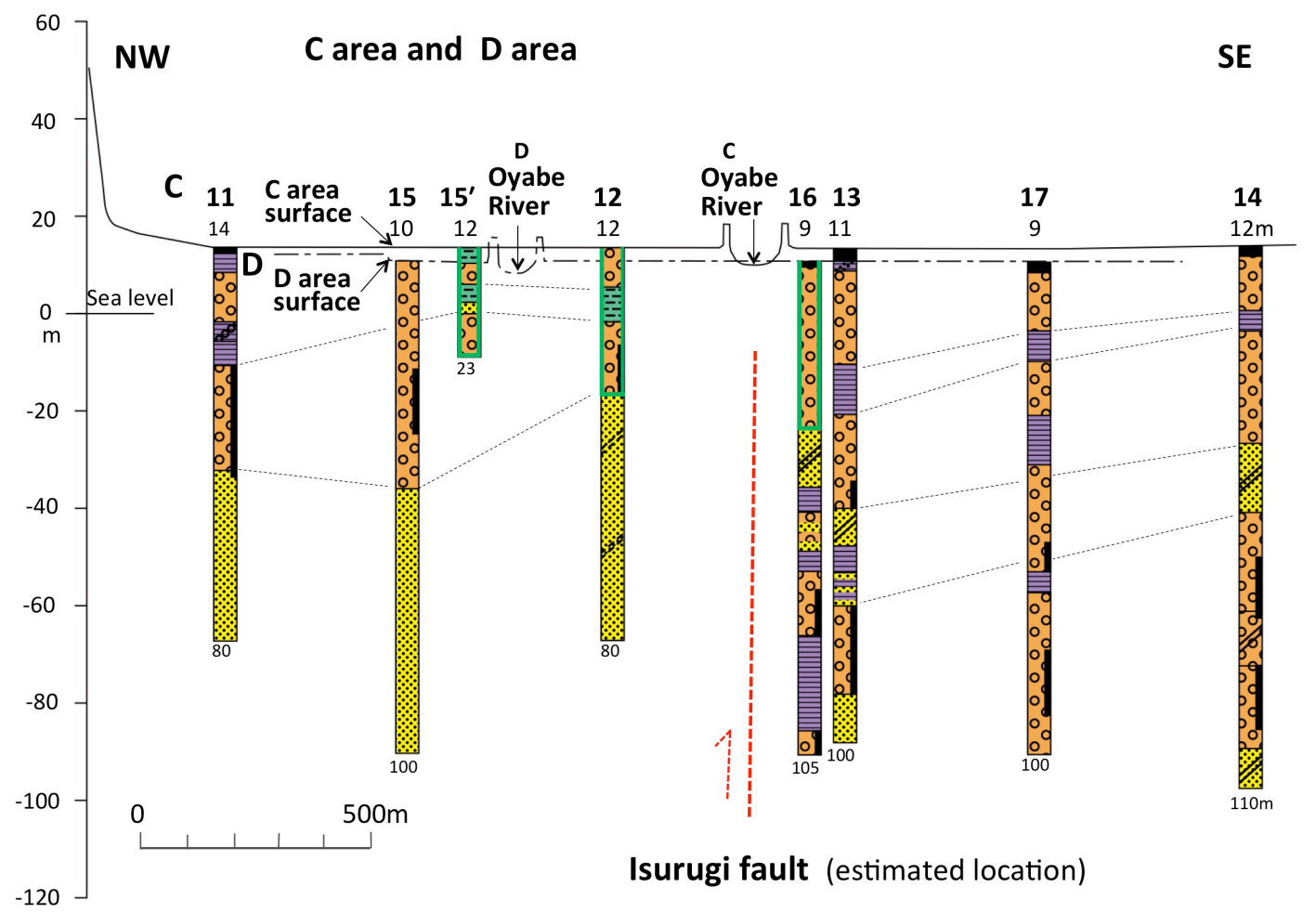

Figure 4. Correlation of borehole logs (number 11 - 17) in C area and D area. 


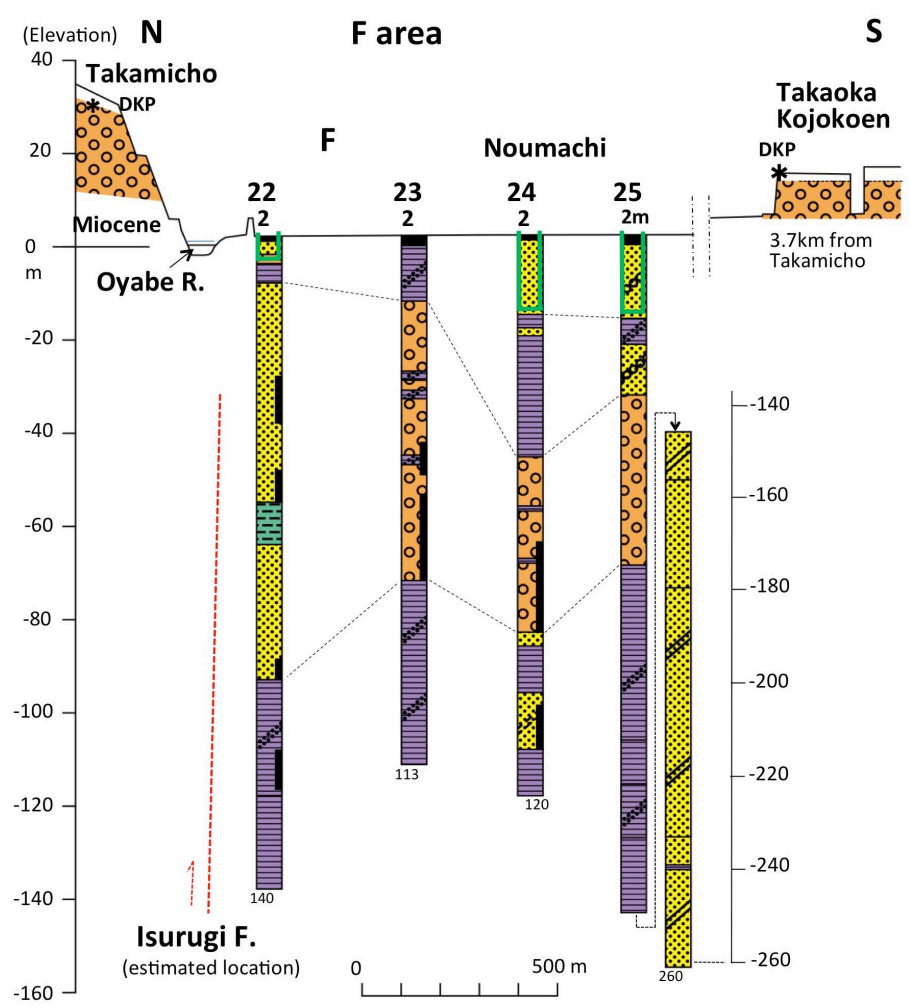

Figure 5. Correlation of borehole logs (number 22 - 25) In F area.
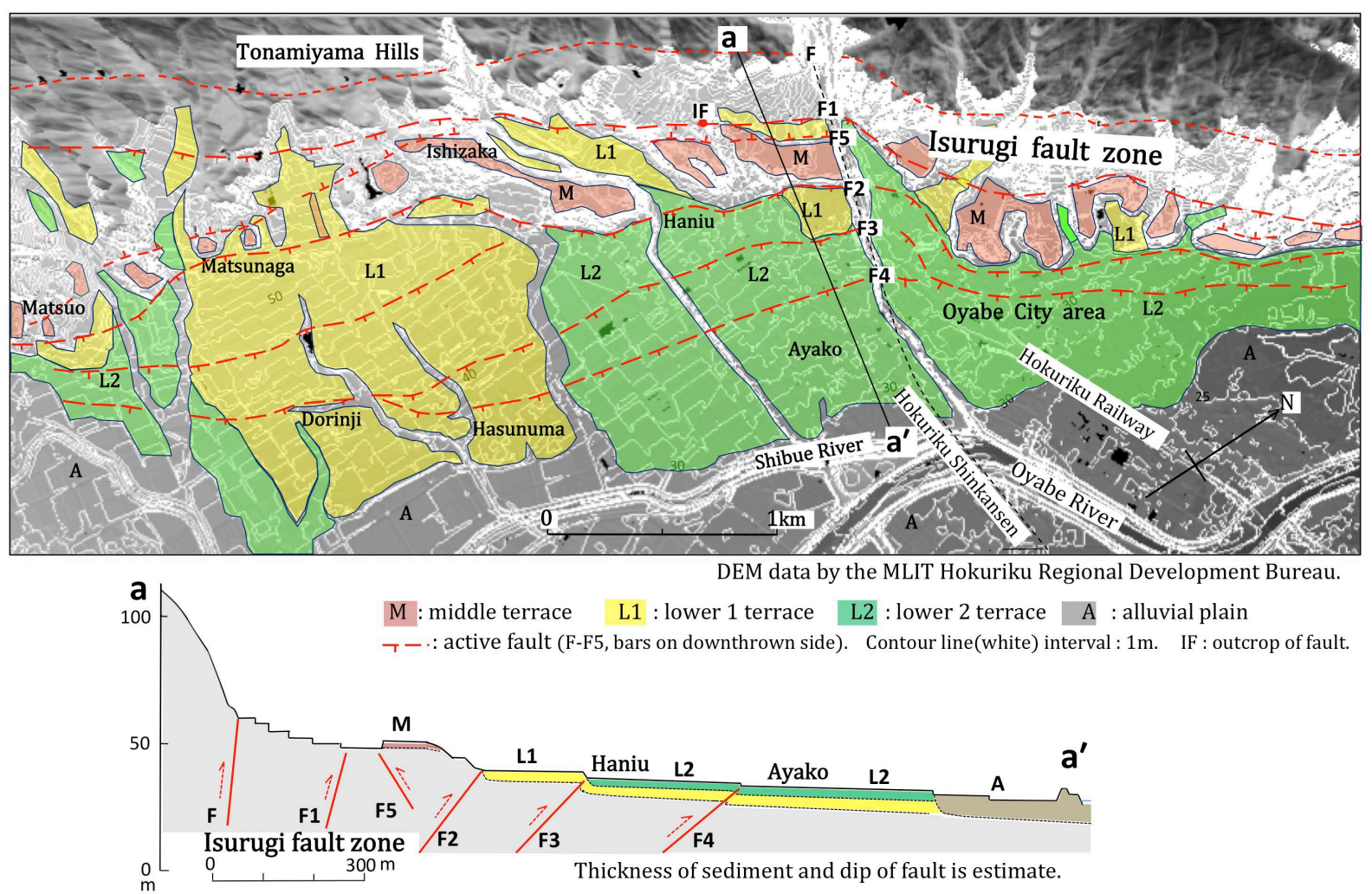

Figure 6. Distribution of terraces and location of Isurugi fault zone estimated in the southern part of Oyabe City. Topographic profile of a-a'. (Topographic profile of the terraces was from a 1:5000 national basic map). 
[24] conducted a trench survey of the Horinji fault in the Horinji area (Ho of Figure 2). The survey confirmed the existence of lower terrace sediments containing AT tephra in their lower layer, between sand and silt, and the existence of a reverse fault, the mountain side of which was uplifted. The fault cut the Holocene sediments. The sediments were dated, and from the results it was estimated that the most recent period of activity of the fault was roughly 5600 years ago (Figure 7). In addition, it was estimated that the fault may extend northward in a concealed form.

[31] published the location of the Takaoka fault on the northern part of the Tonami Plain (Figure 2). The Takaoka fault is estimated to have an uplift on the western side that runs from the southern part of the city of Takaoka along the east of Takaoka kojo-park and then extends to the Fushiki area. Because the fault's southern end is close to the northern extension of the Horinji fault, connections between the two faults are also suspected.

\subsubsection{The Takashozu Fault}

The Takashozu fault lies at the northwestern foot of the Takashozu Mountains and trends NE-SW (Figure 2). In the southern part of the Akasobu reservoir in Nanto (Ak of Figure 2), [13] confirmed the existence of an outcrop of a reverse fault in which the Iwaine formation is pushed up on top of the lower terrace gravel; Takemura also showed that the Takashozu fault is an active fault (Figure 8).

In addition, in a trench survey of the Takashozu fault in the Tojoji area of Nanto a reverse fault was found (To of Figure 2). The mountain side of the fault was uplifted, and the fault cut through Holocene sediments. A bulge structure thought to accompany a low-angle reverse fault was also observed (Figure 9).

The period of activity of this fault was estimated to be between 4205 and 3678 years ago [30]. According to [32] and [33], the northeastern extension of the Takashozu fault is estimated to pass through the Inami area of Nanto and reach the middle terrace on the right bank of the Sho River in the city of Tonami. This extends the length of the fault to roughly $21 \mathrm{~km}$.

The fault that runs obliquely to the Takashozu fault is the Johana-Kaminashi fault. It trends NNW-SSE and cuts across the western part of the Takashozu Mountains (Figure 1). [34] pointed out that the geological features differ markedly between the two sides of the fault. Although there is as yet no confirmed direct proof that the Johana-Kaminashi fault is active, an outcrop of a reverse fault in which the Futomiyama formation is pushed over a lower terrace gravel from the east can be observed in the Futatsuyagawa fault, located immediately west of the Johana-Kaminashi fault [21].

[31] also published the location of the Imizu fault (Figure 2). The fault lies on the eastern part of the Tonami Plain. Because the Takashozu fault lies to the south of the Imizu fault, deep connections between the two are suspected.

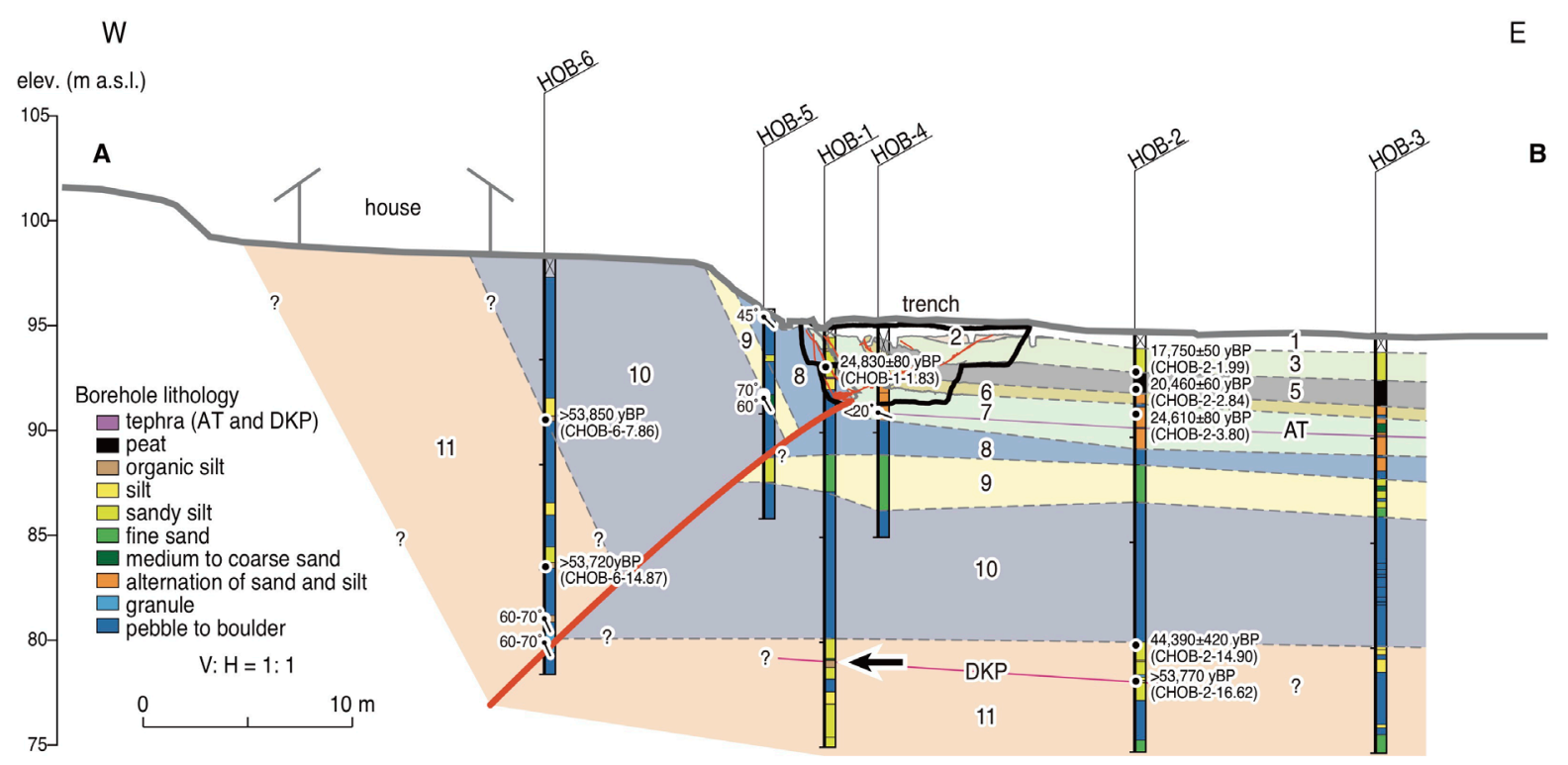

Figure 7. Geologic section across of the Horinji fault at Horinji based on borehole transect. (Modified from [24]). 


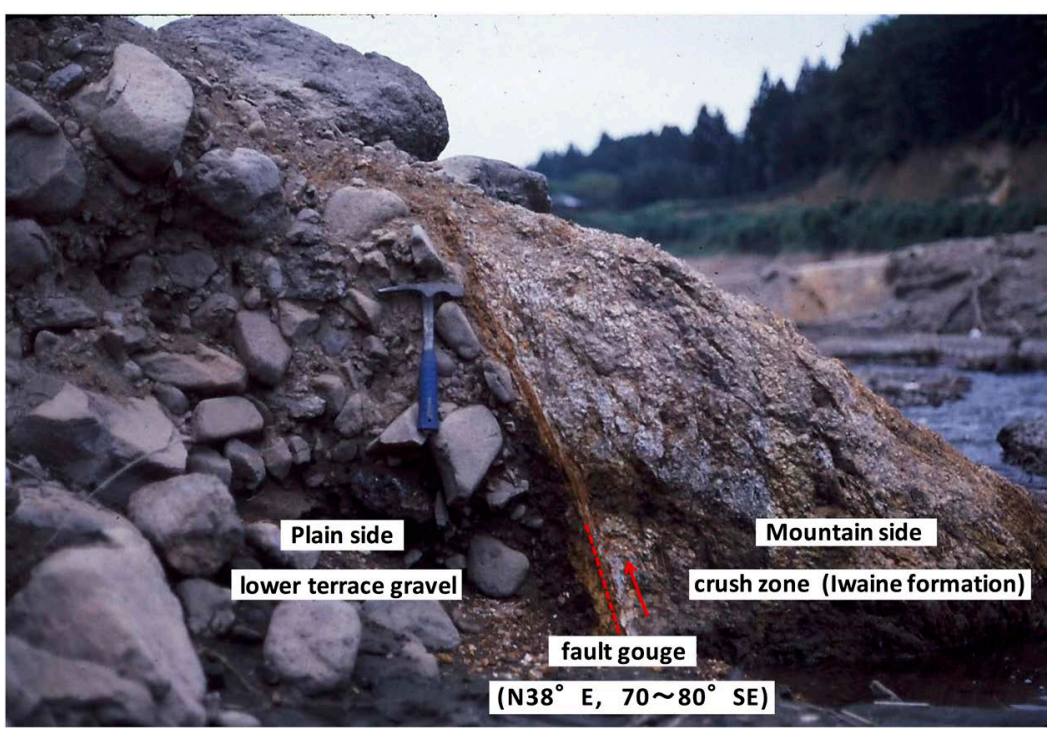

Figure 8. Outcrop of Takashozu fault at the Akasobu reservoir (Ak of Figure 2).

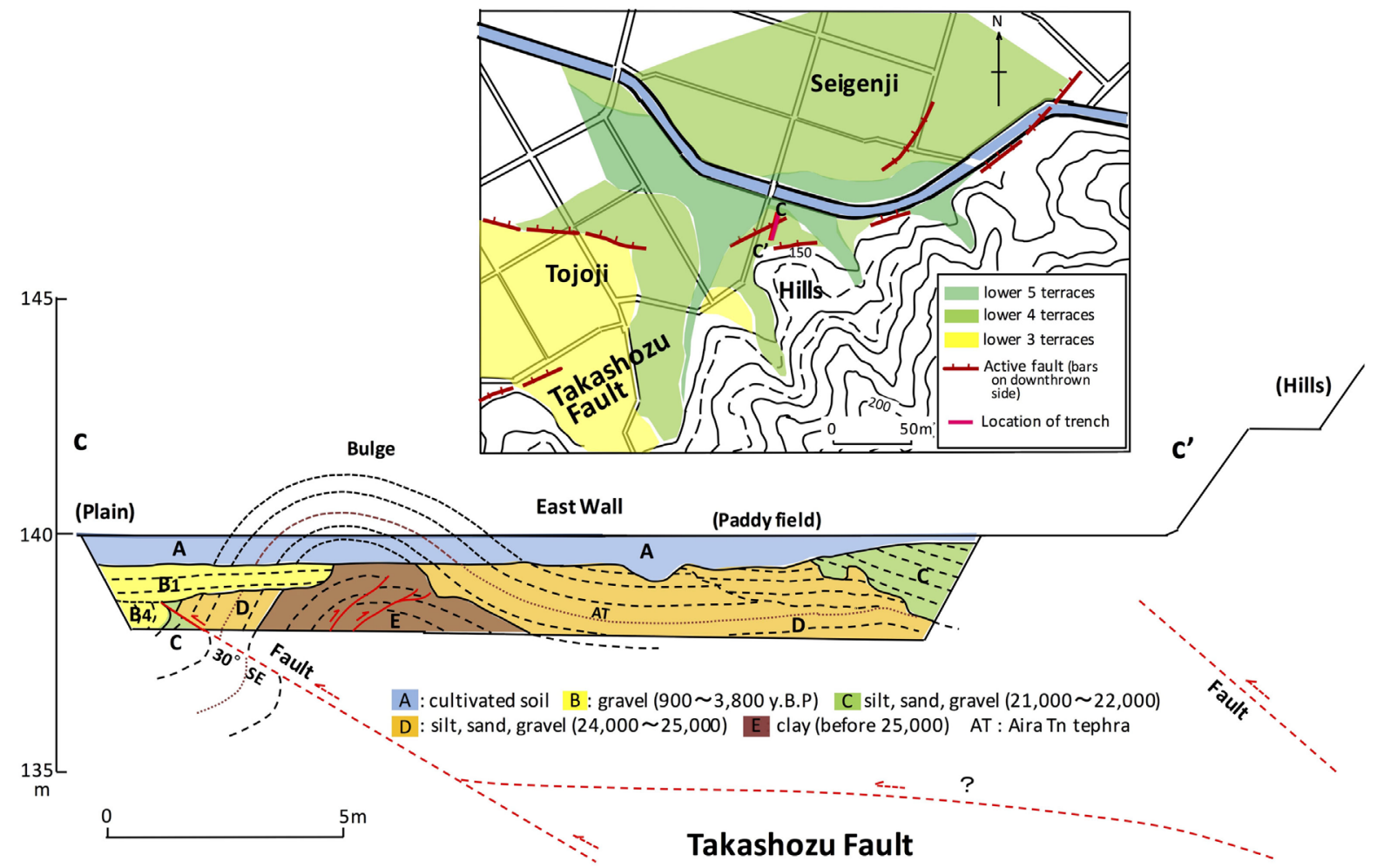

Figure 9. Geological schematic profile of trench in the Tojoji area (Modified from [30]).

\subsubsection{Groups of Active Faults Surrounding the Tonami Plain}

Groups of active faults exist in the area surrounding the Tonami Plain (Figure 1).

The Kurehayama fault trends NE-SW; the northwest side has been uplifted and lies at the southeastern foot of the Kurehayama Hills [1] [35] [36]. The Morimoto-Togashi fault zone is located at the eastern margin of the Kanazawa Plain. It is a reverse fault trending NE-SW, with uplift on the southeast side ([37]; Figure 1). The Ochigata fault zone is located at the southeastern margin of the Ochi Graben. It is a reverse fault trending primarily NE-SW, with uplift on the southeast side, and it includes the Sekidosan fault and others ([38], Figure 1). 
In the Hida Highland to the south of the Tonami Plain, the Kazura fault is located in the northern part of the Shogawa fault zone; it trends NNW-SSE and has left-lateral strike-slip movement and uplift on the west side [39] [40]. The Shogawa fault zone is thought to have caused the large magnitude 7.8 earthquake in 1586 and to have inflicted enormous damage on the area centering on Hida, Mino, and Ecchu [40] [41].

The Ushikubi fault is a large fault located in the northern part of the Hida Highland. It trends ENE-WSW, with right-lateral strike-slip movement and uplift on the north side ([39] [42], Figure 1).

The Atotsugawa fault is a large-scale fault $69 \mathrm{~km}$ long that begins in Shirakawa Village in Gifu Prefecture, cuts across the Takahara River, and reaches the Tateyama Caldera in Toyama Prefecture. It has right-lateral strike-slip movement and uplift on the north side. Its most recent activity is estimated to have been in the magnitude 7.0 to M 7.1 Hietsu earthquake in 1858 ([41] [43], Figure 1).

The above-mentioned groups of active faults should not be seen as having no relevance to the Tonami-heiya fault zone; instead, they should be viewed as having mutual influence in the wide-ranging stress field.

\section{Discussion}

\subsection{Evolution of the Landforms and Geology of the Tonami Plain, and the Behavior of Active Fault Groups in the Middle and Late Quaternary}

In the Quaternary, the compression field trending NW-SE became the prevailing compression field in the Hokuriku region. The present active structure in which an NE-SW direction predominates began to be formed [3], leading to the formation of the Tonami Plain.

The higher terrace gravel is distributed at the foot of the mountains and hills. On the southern part of the Tonami Plain, the higher terrace at the northwestern foot of the Takashozu Mountains is greatly dissected because of the presence of the Takashozu fault at its front. The distribution of terrace gravel and the unevenly formed valleys in the higher terraces of the Kanda Hills seem to suggest that the mountain side of the fault was uplifted through the activity of the Horinji fault after sedimentation of the higher terrace gravel from the Oyabe River.

On the northern part of the Tonami Plain, the higher terrace sediments can be thought to have been carried by the Sho and Oyabe rivers. However, because this area was part of a plain at the time, the Futagami Hills probably existed separately, like separate islands. The presence of anticline extending to the east from Mt. Hodatsu is the likely reason why the higher terrace gravel in this area has been uplifted to its present height. In addition, the influence of the uplifting of the Hodatsu Hills side of the Isurugi fault, which continued into the late Pleistocene, can be assumed to have been large, as supposed by [19]. In an E-W cross-section of the area near the Isurugi fault, at an average depth of $6 \mathrm{~km}$, [44] found a peak-to-peak difference of $2 \mathrm{~km}$. This indicates the large size of the Isurugi fault.

The continued displacement and deformation of middle and lower terraces because of the activity of the Tonami-heiya fault zone- even after the formation of the higher terraces - have already been confirmed through outcrop observations. Generally, the degree of displacement and deformation of older terraces was found to be larger. This indicates the continuation of fault activity in the same manner.

In addition, according to the observation records of a trench survey, the Isurugi fault was most recently active between roughly 4000 and 900 years ago [24], whereas the Horinji fault was most recently active about 5600 years ago [24] and the Takashozu fault between roughly 4205 and 3678 years ago [30]. Thus every one of these faults was estimated to have been active sometime after the middle Holocene.

What is more important is that the ground-surface locations of those faults thought to be the most recently active in the Tonami-heiya fault zone are moving from the foot of the mountain towards the plain. Moreover, the dip of the fault plane tends to be more low-angled than that of the old outcrops. This can be interpreted as indicating the continuation of dynamic fault activity and uplifting of the mountains and hills (Figure 10).

[45] pointed out that, when the mountains at the back of the plain are uplifting, in response, the valleys more actively erode the mountains and discharge soil and sand; the newly created fans at the foot of the mountains cover the old fans in the upper reaches, and the slope becomes steeper. On the other hand, when uplifting of the mountains stops, erosion of the valleys is weakened; the old fans at the foot of the mountains are dissected, and new fans with gentle slopes are created in the lower reaches. At the Hitani River foot of the Takashozu Mountains, new fans are covering the old fans in the upper reaches. And rivers with little relative elevation between the surface of the fan and the river bed can be observed (Hi of Figure 2). 


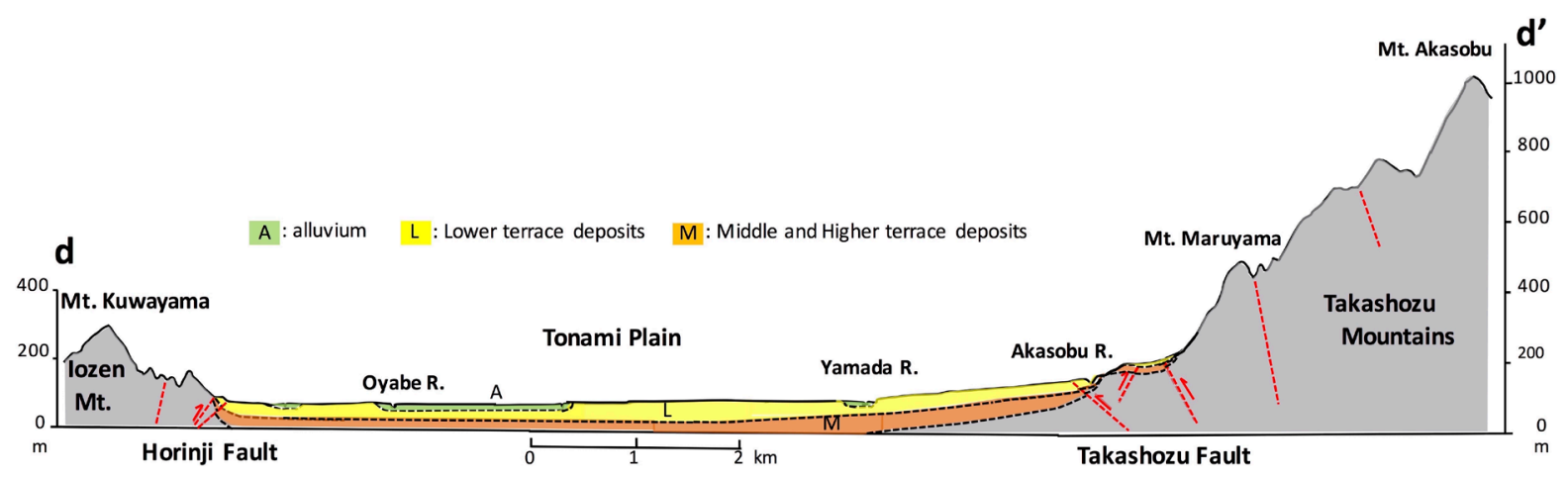

Figure 10. Topographic profile of d-d' and active faults. (Based on 1:25,000 topographic maps and 5 m-DEM data of GSI).

\subsection{Sediments and Tectonic Movements on the Tonami Plain}

As previously stated, [17] estimated the depth of the middle Pleistocene Hanyu formations in the Toide area of Takaoka to be between $40 \mathrm{~m}$ and $440 \mathrm{~m}$.

[18] estimated the depth to the base of the Quaternary strata (the Junicho stratum) to be about $2000 \mathrm{~m}$ and thought that the Horinji fault was heavily involved in the formation of this deep sedimentary basin. In addition, because, according to [19] (pending publication), the Isurugi fault runs along the Oyabe River, the underground of the Tonami Plain can be thought to be a tilted block structure that is greatly affected by this fault.

From an examination of the evolution of the landforms of the Toyama Plain, [46] concluded that the present tectonic movement began at about the beginning of the Quaternary and is still continuing.

\section{Conclusions}

The relationships between the evolution of the landforms and geology of the Tonami Plain and the activity of the Tonami-heiya fault zone in the late Quaternary are summarized as follows:

1) The new estimate of the location of the Isurugi fault in the western part of the Tonami-heiya fault zone places it running from the southern part of Oyabe along the Oyabe River and on to Toyama Bay. The total length is now roughly $30 \mathrm{~km}$, and the estimated rate of displacement by activity is 0.31 to $0.64 \mathrm{~m} / \mathrm{kyr}$.

2) With the beginning of the Quaternary, the direction of the compression axis on the Tonami Plain changed to NW-SE, and groups of NE-SW-trending active faults of the Tonami-heiya fault zone (represented by, for example, the Isurugi, Horinji, and Tokashozu faults) began to be active. These changes thus formed the outline of the present Tonami Plain. As a result, the sedimentary strata that existed before these changes in the sedimentary basin were cut by the faults and were displaced and deformed.

3) Because of the activity of the Tonami-heiya fault zone and the basin-forming movements, the uplifting trend of the mountains and hills and the subsiding trend of the plain continued even after the late Quaternary. For this reason, although the higher, middle, and lower terrace sediments that were piled up in the late Pleistocene were generally accumulated within the plain, because of the ongoing and continuous activity of the faults, displacement and deformation of the terrace surfaces were greater for older terraces. The influence of the enormous active fault groups present in the Hida Highland can be suspected to have affected the activity of the Tonami-heiya fault zone and the process of evolution of the Tonami Plain.

4) The reason why the newer fault outcrops of the Tonami-heiya fault zone are observed on the plain side of the fault and the fault plane is low-angled is probably because all of the faults have continued to uplift on the mountain side since the middle Holocene, while continuing to shift toward the plain side. However, the total displacement of the fault activity is not enough to explain the uplifting and subsidence movements completely.

5) The Tonami Plain measures about 20 to $30 \mathrm{~km}$. However, to the west of the Tonami Plain is the subsidence area of the Kanazawa Plain, with the uplifted area of the Iozen Mountains and the Hodatsu Hills in between. To the east of the Tonami Plain is the subsidence area of the more narrowly defined Toyama Plain, with the uplifted area of the Imizu and Kurehayama Hills in between.

We propose that the primarily NE-SW tectonic movement that has been continuing in the Hokuriku region 
since the late Pliocene and through the Quaternary is a block movement with a wavelength of approximately 20 $\mathrm{km}$ that accompanies faulting and additional long-term foundation folding.

\section{Acknowledgements}

We are grateful to Professors Tohru Watanabe, Shigekazu Kusumoto and Masaaki Shimizu in the Graduate School of Science and Engineering, University of Toyama for guidance during the preparation of this manuscript. We equally acknowledged academic guidance from Dr. Shoji Fujii and Keiji Nakaie of the Institute of Applied Geography, Inc., and Dr. Tadashi Maruyama of the National Institute of Advanced Industrial Science and Technology (AIST). We are indebted to Mrs Emilia B. Fantong and also to Mr. Hiroyuki Yamaguchi, in the Graduate School of Science and Engineering, University of Toyama for reviewing some sentences and for drawing some maps used in this study respectively. More thanks to all who have contributed to this research in one way or the other.

\section{References}

[1] The Headquarters for Earthquake Research Promotion Earthquake Res. Committee (2002) Long-Term Assessment of the Tonami-Heiya Fault Zone• Kurehayama Fault Zone. 28.

http://www.jishin.go.jp/main/chousa/02dec_tonami/index.htm

[2] Sakamoto, T. (1966) Cenozoic of Southern Half in Toyama Sedimentary Basin and Its Tectonic History. Geological Survey of Japan Report, 213, 1-28.

[3] Takeuchi, A. (2010) Geologic Structure and Late Cenozoic Evolution of the Hokuriku and Shinetsu Regions, NorthCentral Japan. The Journal of the Geological Society of Japan, 116, 624-635. http://dx.doi.org/10.5575/geosoc.116.624

[4] Ministry of Land, Infrastructure and Transport Hokuriku Development Bureau (2007) Laser Profiler Data “ Joganji River•Jinzu River• Sho River• Oyabe River Drainage System (Toyama Prefecture)”.

[5] Geospatial Information Authority of Japan (2015) 5m Mesh DEM Data. http://www.gsi.go.jp/Map/CD-POM/dem5m/index.html

[6] Kobayashi, T., Eds. (2000) Explore the Earth—Toyama and Hida Mountains. Daichi Co., Ltd., 256 p.

[7] Okubo, H., Sato, T. and Watanabe, M. (2000) Stratigraphic Correlation between the Plio-Pleistocene Yabuta and Junicho Formations Using Volcanic Ash Beds, and Diatom and Calcareous Nannofossil Biostratigrahy of Lower Part of the Junicho Formation in Northwestern Toyama Prefecture, Central Japan. The Journal of the Geological Society of Japan, 106, 583-596. http://dx.doi.org/10.5575/geosoc.106.583

[8] Endo, K. and Kobayashi, T. (2012) Quaternary. Kyoritsu-Pub. Co., Ltd., 231.

[9] Fujii, S., Takemura, T. and Yamamoto, O. (1976) Isurugi Mobile—Quaternary Crustal Movement in Toyama Sedimentary Basin. Abstracts the 83th Annual Meeting the Geological Society of Japan, 110.

[10] Sumi, Y., Nozawa, T. and Inoue, M. (1989) Geology of the Isurugi District. Quadrangle Series Scale 1:50,000, Kanazawa (10) No.21. Geological Survey of Japan, 118.

[11] Machida, H. and Arai, F. (2003) Atlas of Tephra in and around Japan [Revised Edition]. University of Tokyo Press, Tokyo, 336.

[12] Oyabegawa Danken Group (1974) Quaternary of Southern Hills in Tonami Plain. Memoirs of the Toyama Geographical Society, 6, 129-137.

[13] Takemura, T. (1978) The Tectonic Displacement of the Tonami Plain, Toyama Prefecture. Geographical Review of Japan, 51, 721-729. http://dx.doi.org/10.4157/grj.51.721

[14] Nakamura, Y. (2002) Late Quaternary Activity of the Takashozu and Hohrinji Faults along the East and West Margins of the Tonami Plain, Toyama Prefecture, Central Japan. The Quaternary Research, 41, 389-402. http://dx.doi.org/10.4116/jaqua.41.389

[15] Kamishima, T., Nishida, S. and Utsukawa, T. (1989) Distribution of Widespread Volcanic Ash in the Toyama Prefecture-Mainly for the DKP and AT-. Memoirs of the Toyama Geographical Society, 9, 23-34.

[16] Ministry of Construction Hokuriku Construction Bureau Hokuriku technology Office (1979) Ground Diagram Compilation of Plains in Toyama Prefecture 1-4.

[17] Japan National Oil Corporation (1984) Showa 59 Year Foundation Drilling “Toyama” Data of Geological Study Meeting.

[18] Fujiwara, O. (2001) Subsidence Map in the Quaternary Tectonic Basins. In: Koike, K. and Machida, H., Eds., Atlas of 
Quaternary Marine Terraces in the Japanese Islands, University of Tokyo Press, Tokyo, 85-96.

[19] Kamishima, T. and Takeuchi, A. (Pending Publication) Location and Activity of the Isurugi Fault in the Western Part of the Tonami-Heiya Fault Zone, Central Japan.

[20] Fujii, S. and Onogi, K. (1967) Quaternary of Isurugi Town District, Western Part of Toyama Prefecture. Commemorative Volume Published on a Professor Sassa Yasuo’s Sixtieth Birthday, 335-363.

[21] Fujii, S. and Takemura, T. (1979) Active Faults in the Toyama Prefecture and Surrounding Area. Toyama Prefecture Earthquake Measures Basic Research Report, 39-72.

[22] Takemura, T. (1983) Active Faults in Toyama Prefecture. Chikyu Monthly, 5, 431-436.

[23] Research Group for Active Fault of Japan (Eds.) (1991) Active Faults in Japan: Sheet Maps and Inventories. University of Tokyo Press, Tokyo, 437. [Revised Edition]

[24] National Institute of Advanced Industrial Science and Technology (2012) Research on Fault Activity and History of the Tonami Heiya Fault Zone and the Kurehayama Fault Zone (Western Part of the Tonami Heiya Fault Zone). Report on Complementary Investigation of Active Fault H23-1, 27.

[25] Maruyama, T. and Saito, M. (2015) Geologic Evidence for Late Quaternary Repetitive Surface Faulting on the Isurugi Fault along the Northwestern Margin of the Tonami Plain, North-Central Japan. Island Arc, 24, 188-204. http://dx.doi.org/10.1111/iar.12110

[26] Earthquake Research Institute (2015) Sea of Japan Earthquake and Tsunami Research Project (2-4) Terrestrial Active Structure Investigation, H26 Years Second Steering Committee Data. University of Tokyo, 18p. (URL)

[27] Ishiyama, T., Sato, H. and Kato, N. (2015) Structural Characters of Active Faults in the Toyama Sedimentary Basin Revealed by Shallow to Deep Seismic Profiling. Japan Geoscience Union Meeting 2015, Chiba-City, 24-28 May 2015, SSS28-10.

[28] Toyama Prefecture (1998) Summary Report on Survey of the Tonami-Heiya Fault Zone. Toyama Prefecture, 20.

[29] Toyama Prefecture (1999) Summary Report on Survey of the Tonami-Heiya Fault Zone. Toyama Prefecture, 18.

[30] Toyama Prefecture (2000) Summary Report on Survey of the Tonami-Heiya Fault Zone. Toyama Prefecture, 30.

[31] Goto, H., Okada, S., Kagohara, K., Sugito, N. and Hirakawa, K. (2015) 1:25,000 Active Fault Maps in Urban Area, Takaoka. http://maps.gsi.go.jp/?z=14\&base=std\&11=36.7333335,136.955556\&1s=afm

[32] Togo, M. (2000) The Active Fault Interpretation by the Minute Topography. Kokon Shoin, 207.

[33] Tsutsumi, H., Togo, M., Imaizumi, T., Nakamura, Y., Kaneda, H. and Hirouchi, D. (2003) 1:25,000 Active Fault Maps in Urban Area, Tonami. Geographical Survey Institute.

[34] Ikebe, N. (1950) Geology of Takashozu Mountains. Shizen to Shakai (The Nature and Society), 5-6, 12-16.

[35] Toyama Prefecture (1997) Summary Report on Survey of the Kurehayama Fault Zone. Toyama Prefecture.

[36] The Headquarters for Earthquake Research Promotion Earthquake Research Committee (2008) For Some Revision of the Assessment of Tonami-Heiya Fault Zone Kurehayama Fault Zone, 47.

http://www.jishin.go.jp/main/chousa/katsudansou pdf/56 tonami kureha 2.pdf

[37] The Headquarters for Earthquake Research Promotion Earthquake Research Committee (2013) Long-Term Assessment of Morimoto Togashi Fault Zone (For Some Revision), 18. http://www.jishin.go.jp/main/chousa/13nov_morimoto/index.htm

[38] The Headquarters for Earthquake Research Promotion Earthquake Research Committee (2005) Long-Term Assessment of Ochigata Fault Zone, 12. http://www.jishin.go.jp/main/chousa/05mar ouchigata/

[39] Takemura, T. and Fujii, S. (1984) Active Faults in the Northern Part of the Hida Mountains, Central Japan. The Quarternary Research, 22, 297-312.

[40] The Headquarters for Earthquake Research Promotion Earthquake Research Committee (2004) Long-Term Assessment of the Syogawa Fault Zone, 24. http://jishin.go.jp/main/chousa/04sep_syogawa/index.htm

[41] National Astronomical Observatory of Japan (Ed). (2015) Chronological Scientific Tables 2015. Maruzen Publishing Co., Ltd., 1092.

[42] The Headquarters for Earthquake Research Promotion Earthquake Research Committee (2005) Long-Term Assessment of Ushikubi Fault Zone, 30. http://www.jishin.go.jp/main/chousa/05mar_ushikubi/index.htm

[43] The Headquarters for Earthquake Research Promotion Earthquake Research Committee (2004) Long-Term Assessment of the Atotsugawa Fault Zone, 16 p. http://jishin.go.jp/main/chousa/04sep_atotsugawa/index.htm

[44] Uda, T. and Kusumoto, S. (2013) Subsurface Structures of Toyama Basin Estimated by Bouguer Gravity Anomaly. Japan Geoscience Union Meeting 2013, Tokyo, 19-24 May 2013. 
[45] Keiier, E.A. and Pinter, N. (2002) Active Tectonics Earthquakes, Uplift, and Landscape. Prentice Hall Inc., Upper Saddle River, 362.

[46] Machida, H., Matsuda, T., Umitsu, M. and Koizumi, T. (2006) Regional Geomorphology of the Japanese Islands, Vol. 5, Geomorphology of Chubu Region, University of Tokyo Press, Tokyo, 385.

\section{Submit or recommend next manuscript to SCIRP and we will provide best service for you:}

Accepting pre-submission inquiries through Email, Facebook, Linkedin, Twitter, etc A wide selection of journals (inclusive of 9 subjects, more than 200 journals)

Providing a 24-hour high-quality service

User-friendly online submission system

Fair and swift peer-review system

Efficient typesetting and proofreading procedure

Display of the result of downloads and visits, as well as the number of cited articles

Maximum dissemination of your research work

Submit your manuscript at: http://papersubmission.scirp.org/ 